\title{
Ontogeny of Epidermal Growth Factor Receptor/ Kinase and of Lipocortin-1 in the Ovine Lung ${ }^{1}$
}

\author{
MAHLON D. JOHNSON, MARY E. GRAY, GRAHAM CARPENTER, R. BLAKE PEPINSKY, \\ HAKAN SUNDELL, AND MILDRED T. STAHLMAN \\ Departments of Pathology [M.D.J., M.E.G.], Biochemistry [G.C.] and Pediatrics [H.S., M.T.S.], Vanderbilt \\ University, School of Medcicine, Nashville, Tennessee 37232, and Biogen Research Corporation, \\ Cambridge, Massachusetts 02142 [R.B.P.]
}

\begin{abstract}
We have examined the ontogeny and distribution of the epidermal growth factor receptor/kinase (EGF receptor) and of lipocortin-1, a major cellular substrate of the EGF receptor, in a developmental series of 13 normal ovine fetal lungs (44-145 $d$ of gestation) using the peroxidase anti-peroxidase technique with two extensively characterized polyclonal antibodies recognizing the EFG receptor and one polyclonal antibody recognizing lipocortin-1. Immunoreactive EGF receptor/kinase and lipocortin1 were detected in conducting airway epithelium by the end of the first trimester of pregnancy before bronchial glands could be identified. This was followed at two-thirds of gestation by immunoreactivity in bronchial glands and large bronchioles adjacent to postive bronchi. By seveneighths of gestation conducting airway epithelium no longer contained consistently detectable immunostaining for EGF receptor, although lipocortin-1 was identified until term in all levels of conducting airways. In contrast, neither EGF receptor nor lipocortin-1 immunoreactivity was detected in alveolar type I or type II epithelial cells, fibrocytes, chondrocytes, smooth muscle, or endothelial cells at any gestational age. These findings suggest that EGF receptor and lipocortin-1 may participate in early airway development. (Pediatr Res 25:535-541, 1989)
\end{abstract}

\section{Abbreviations}

EGF, epidermal growth factor

PAP, peroxidase-antiperoxidase

EGF is a 53 -amino acid polypeptide found in many mammalian tissues including the lung (1-3). Administration of EGF stimulates proliferation of epithelial cells in vivo in the lungs of fetal and newborn lambs (4), accelerates lung maturation in fetal rabbits (5), and induces increased thymidine uptake in rat type II cells in vitro (6). EGF also enhances synthesis of surfactant associated-protein by type II cells (7) and phosphatidylcholine synthesis in fetal rat lung explants (8). These effects are thought to be initiated by growth factor binding to high affinity EGF receptors recently identified in cultured type II cells and in fetal rabbit lung homogenates (9); however, the localization of the EGF receptor in intact lung has not been demonstrated.

Received September 29, 1988; accepted December 27, 1988

Correspondence and reprint requests: Dr. Mildred Stahlman, Professor of Pediatrics and Pathology, Vanderbilt University, School of Medicine, Nashville, TN 37232 .

Supported by NIH Grants HL 37726, CA 24071, and SCOR HL 14214.

Presented in part at the meetings of the American Pediatric Society, Society for Pediatric Research, Washington, DC, May 1988.
The EGF receptor is a transmembrane protein containing an extracellular EGF binding site and an intracellular tyrosine kinase domain (10-12). Binding of EGF to the receptor activates the kinase activity which in turn catalyzes the phosphorylation of specific cytoplasmic proteins and of the receptor itself $(10$ 11). Recent work has identified lipocortin-1, a $35 \mathrm{kD}$ protein (p35), as a major physiologic substrate for the EGF receptor/ kinase (13-15). In in vitro assays, lipocortin-1 has been shown to inhibit phospholipase $\mathrm{A}_{2}$ and bind calcium, acidic phospholipids and actin filaments (16-18); however, the cellular function of lipocortin-1 is unknown. Lipocortin- 1 has been found at high concentrations in the mouse and rat lung (17) and has also been isolated from bovine lung (19); however, its distribution in the lung has not been described.

The present study evaluates the ontogeny and distribution of EGF receptor immunoreactivity and lipocortin-1 immunoreactivity in a developmental series of fetal lamb lungs. In the developing ovine lung, both proteins showed a similar cellular distribution confined to bronchi, bronchioles and bronchial glands.

\section{MATERIALS AND METHODS}

The ontogeny and distribution of EGF receptor and lipocortin1 immunoreactivity were analyzed in a series of 13 normal ovine fetuses from time-dated pregnancies (20) of 44-145 d of gestation (term gestation is $147 \mathrm{~d}$ ). Lungs from Hamshire or Suffolk ovine fetuses were rapidly collected after delivery by cesarean section after the ewe and fetus were killed by secobarbital overdose. Gestational ages of the lambs are listed in Table 1. Right lungs of the tiny 44- and 51-d old fetuses were collected without separation into lobes for EGF receptor immunohistochemistry. At these times, the wt of these fetuses ranged from 9.5 to $19.2 \mathrm{~g}$, and the crown-rump lengths ranged from 6.8 to $8.5 \mathrm{~cm}$. In fetuses of $75 \mathrm{~d}$ or older, a time when fetal wt had increased to $235 \mathrm{~g}$ and the crown-rump length to $20.5 \mathrm{~cm}$, sections from two or three lobes from each lamb lung were evaluated for EGF receptor. Blocks from one or two lobes from each lung, fixed both in $10 \%$ formalin and Gendre's fluid and embedded in paraffin, were evaluated for lipocortin-1 immunoreactivity. Each lung was sectioned, evaluated for gross abnormalities, and tissue for EGF receptor immunoanalysis was rapidly frozen in liquid nitrogen for storage at $-80^{\circ} \mathrm{C}$. Frozen sections $5 \mu \mathrm{m}$ thick were cut from each lung at $-20^{\circ} \mathrm{C}$ and thaw-mounted onto aminoalkylsilane-coated microscope slides (21). Sections were fixed in freshly prepared phosphate-buffered $4 \%$ paraformaldehyde $\mathrm{pH}$ 7.6 for $15 \mathrm{~min}$, rinsed in $70 \%$ ethanol for $10 \mathrm{~min}$, and stored at $-20^{\circ} \mathrm{C}$. Additional tissue for identification of lipocortin- $1 \mathrm{im}-$ munoanalysis was fixed in $10 \%$ phosphate-buffered formalin and Gendre's fluid, paraffin embedded, sectioned at $5 \mu \mathrm{m}$ and mounted on aminoalkylsilane-coated slides (21). A human epi- 
Table 1. Appearance of EGF receptor immunoreactivity in the developing lamb lung*

\begin{tabular}{cccccc}
\hline & \multicolumn{4}{c}{ Bronchi } & Bronchioles \\
Lamb & Gestational & $\begin{array}{c}\text { Lining } \\
\text { No. }\end{array}$ & age (d) & Bronchiolo- \\
epithelium & Glands & $\begin{array}{c}\text { lineolar } \\
\text { epithelium } \\
\text { portals }\end{array}$ \\
\hline 1 & 44 & 0 & 0 & - & 0 \\
2 & 44 & 0 & 0 & $\pm \S$ & 0 \\
3 & 51 & + & 0 & - & 0 \\
4 & 75 & ++ & 0 & + & 0 \\
5 & 75 & ++ & 0 & + & 0 \\
6 & 90 & + & \pm & - & - \\
7 & 108 & + & ++ & + & - \\
8 & 117 & ++ & ++ & + & - \\
9 & 129 & + & ++ & - & - \\
10 & 141 & - & + & + & - \\
11 & 142 & - & - & + & - \\
12 & 144 & - & ++ & + & + \\
13 & 145 & + & ++ & + & \pm \\
\hline
\end{tabular}

$*++$, heavy staining; + , faint staining; \pm , questionable staining; - , no staining identified; 0 , structure not in section; $\S$, largest conducting airways but no intrapulmonary cartilage present.

dermal carcinoma cell line (A-431), previously shown to possess $2.5 \times 10^{6} \mathrm{EGF}$ receptor/cell, was used as a positive control for EGF receptor immunoreactivity. A-431 cells (American Type Culture Collection, Rockville, MD), grown using previously out- lined methods, were injected at concentrations of $1 \times 10^{6}$ cells (22) into irradiated nu/nu (nude) mice to produce tumors harvested $14 \mathrm{~d}$ later (23). These tumors were frozen in liquid nitrogen and stored at $-80^{\circ} \mathrm{C}$ or fixed and sectioned as described above. A-431 cell tumors, sheep skin, and placenta containing high concentrations of lipocortin- 1 were used as positive controls for lipocortin-1 immunoreactivity $(13,24)$.

Immunohistochemistry. Epidermal growth factor receptor immunoreactivity was localized utilizing two extensively characterized polyclonal antibodies produced after immunization with either a native form (\#451) or a denatured form (\#310) of the EGF receptor (24-26) and the PAP method (27). Both antisera exhibited optimal immunoreactivity only in frozen sections. Greater immunoreactivity in frozen control tissues denatured with paraformaldehyde was frequently seen with the \#310 antibody raised against denatured EGF receptor. However, the pattern of distribution was similar with both antibodies. The specificity of these antibodies for EGF receptor has been established by ablation studies with EGF receptor-rich membranes of epidermoid carcinoma (A-431) cells (28). Specificity was also assessed by absorption of the antisera to cultures of A-431 cells.

Lipocortin-1 immunoreactivity was localized in tissue fixed in $10 \%$ formalin and in Gendre's fluid using a polyclonal rabbit antibody to recombinant human lipocortin-1 (Biogen Research Corp., Cambridge, MA). The specificity of this antibody was assessed by preabsorption of the minimum effective concentration of antiserum (1:5000 dilution) with $1.0 \mathrm{mg}$ of recombinant lipocortin-1 bound to cyanogen-bromide-activated sepharose $4 \mathrm{~B}$
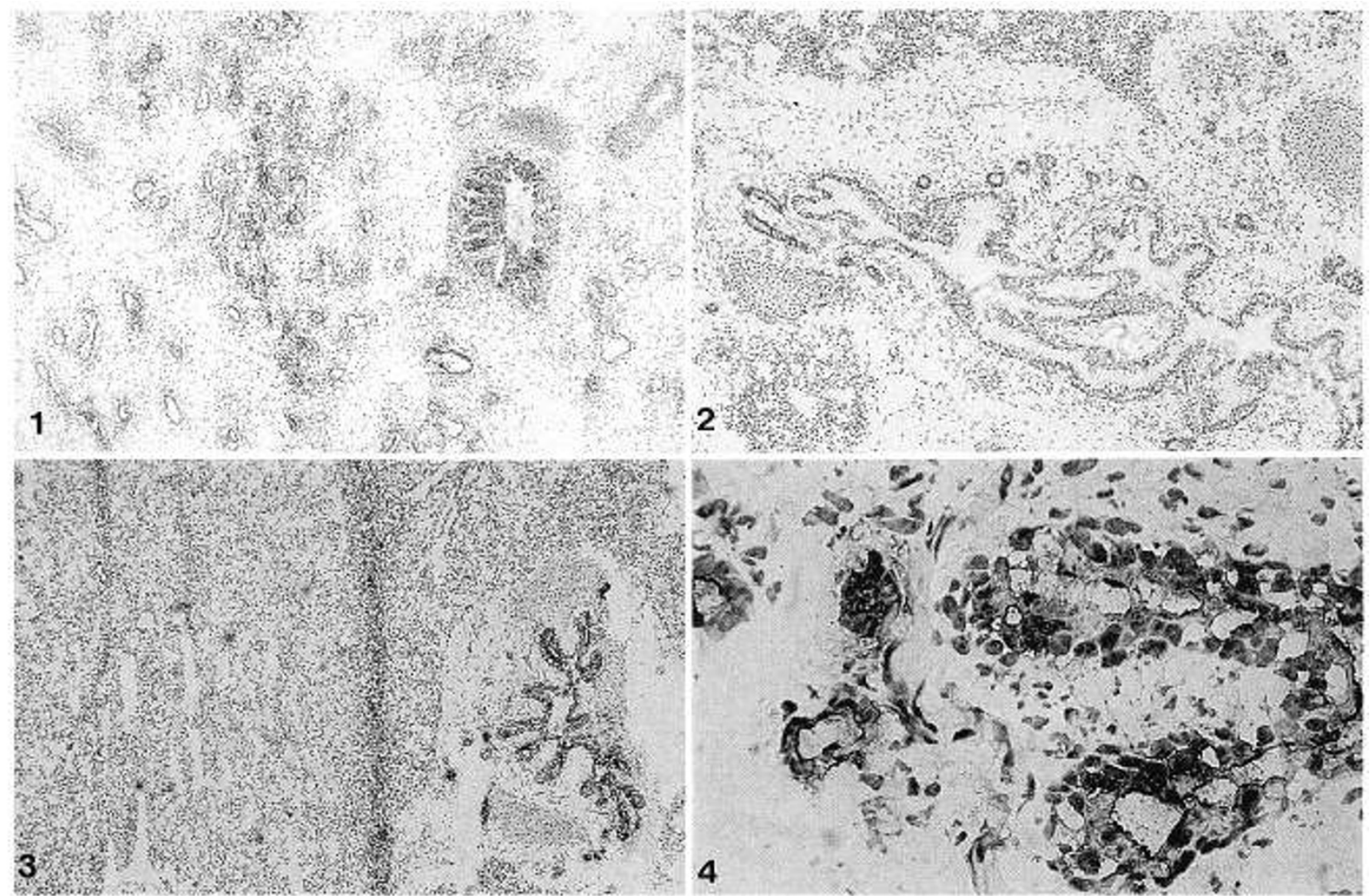

Fig. 1. Photomicrograph of the lung of a lamb of $75 \mathrm{~d}$ of gestation showing extensive immunostaining of the epithelium of a small bronchus for EGF receptor using antibody \#310. No glands are identified. The lung parenchyma is not immunostained (frozen section, immunoperoxidase and hematoxylin $\times 48$ ).

Fig. 2. Photomicrograph of the lung of a lamb of 108 days gestation. Bronchial submucosal glands are immunostained for EGF receptor using antibody $\# 310$ (frozen section, immunoperoxidase and hematoxylin $\times 60$ ).

Fig. 3. Photomicrograph of the lung of a lamb of $117 \mathrm{~d}$ of gestation. Bronchial epithelial lining and submucosal glands are immunostained for EGF receptor using antibody \#310 (frozen section, immunoperoxidase and hematoxylin $\times 48$ ).

Fig. 4. Detail of Figure 3 showing immunostaining of cells lining crypts and submucosal glands of the bronchus seen in Figure 3 . The most intense immunostaining for EGF receptor is at the luminal surface (frozen section, immunoperoxidase and hematoxylin $\times 480$ ). 


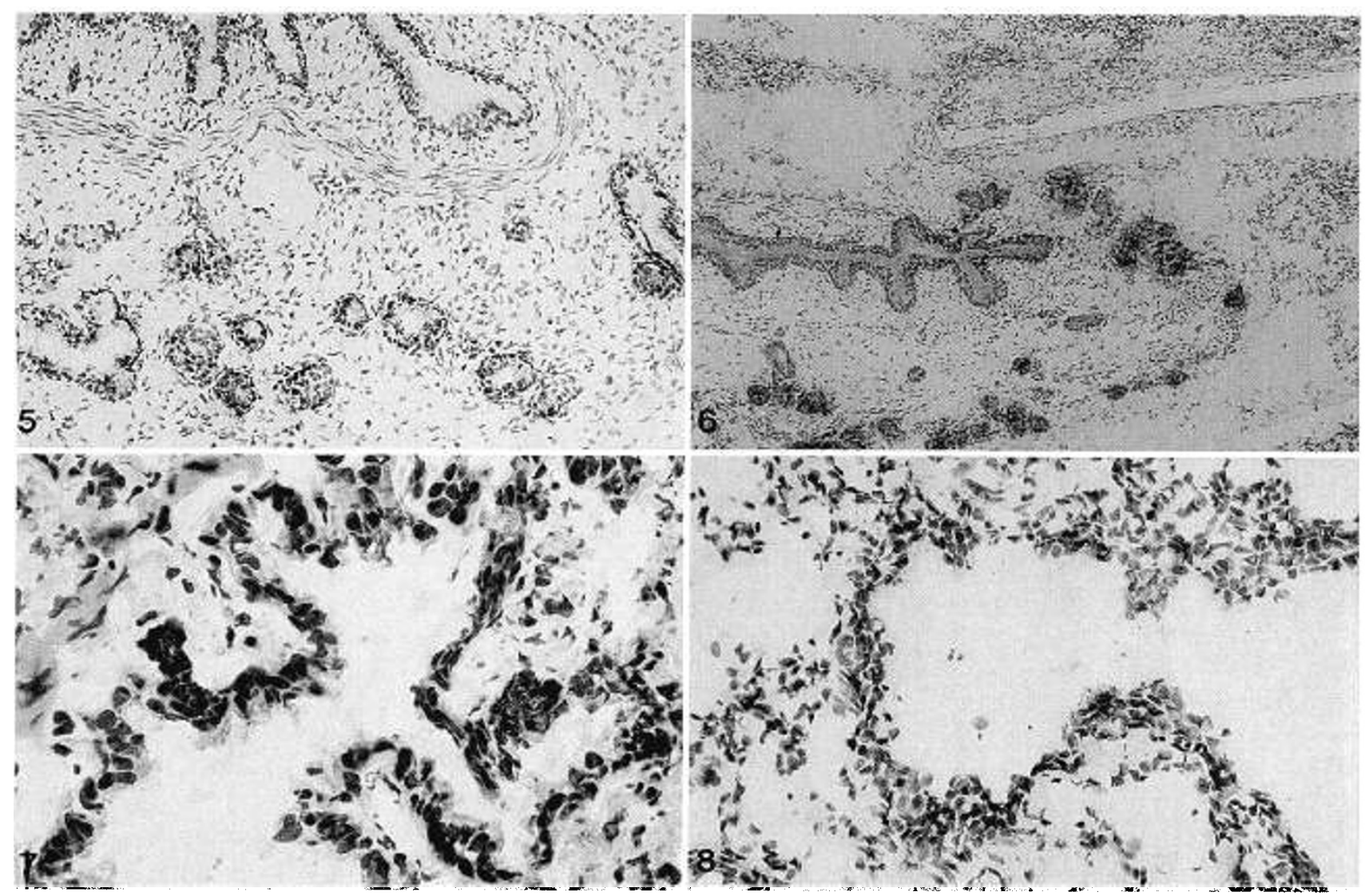

Fig. 5. Photomicrograph of the lung of a lamb of $129 \mathrm{~d}$ of gestation. Bronchial submucosal glands are extensively immunostained for EGF receptor using antibody $\# 310$ (frozen section, immunoperoxidase and hematoxylin $\times 120$ ).

Fig. 6. Photomicrograph of the lung of a lamb of $144 \mathrm{~d}$ gestation. Submucosal bronchial glands are intensely immunostained for EGF receptor as well as is fluid filling the bronchial lumen using antibody \#310 (frozen section, immunoperoxidase and hematoxylin $\times 78$ ).

Fig. 7. Photomicrograph of the lung of a lamb of $141 \mathrm{~d}$ of gestation. Bronchiolar epithelium is lightly immunostained for lipocortin-1 in cells lining deep folds (immunoperoxidase and hematoxylin $\times 480$ ).

Fig. 8. Photomicrograph of the lung of the same lamb as in Figure 6 showing immunostaining for EGF receptor at the bronchiolo-alveolar portal using antibody $\# 310$ (frozen section, immunoperoxidase and hematoxylin $\times 480$ ).

(Sigma Chemical Co., St. Louis, MO) before use on control tissues and on four sections of lung previously found to contain extensive lipocortin-1 immunoreactivity (29). Lipocortin-1 antiserum does not react with lipocortin-2 (30).

Sections of lung as well as placenta were washed in a solution of $0.5 \%$ hydrogen peroxide in $100 \%$ methanol for $10 \mathrm{~min}$, then preincubated with $10 \%$ normal swine serum in PBS (pH 7.6). After blotting, sections were incubated overnight at room temperature with either primary antisera against EGF receptor or lipocortin-1, then sequentially incubated with swine antirabbit immunoglobulin (dilution 1:20) and rabbit PAP (dilution 1:50) for 30 min each. All incubations were followed by rinsing and two 10 -min washes in PBS. The tissues were subsequently exposed to the peroxidase substrate 3,3'diaminobenzidine (DAB; Sigma) $0.5 \mathrm{mg} / \mathrm{mL}$ in $0.05 \mathrm{M}$ Tris $(\mathrm{pH} 7.6)$ containing $0.05 \%$ hydrogen peroxide (28). Slides were counterstained with hematoxylin.

Extensive EGF receptor immunoreactivity was seen in all viable cells of the A-431 cell tumor. Immunoreactivity was not seen in endothelial cells lining vascular spaces or in fibroblasts making up the capsule surrounding the tumor. EGF receptor immunoreactivity was completely ablated by preabsorption on A-431 cells. EGF receptor immunoreactivity was also seen throughout the epidermis of ovine skin with greatest intensity in keratinocytes populating the basal and spinous layers.

Extensive lipocortin-1 immunoreactivity was also seen in sections of tumors from A-431 cells. Intravascular neutrophils also immunostained. Immunoreactivity was seen at dilutions of
1:250-1:5000 with an optimal signal to noise ratio at 1:1000 1:2000. Lipocortin-1 immunoreactivity was also demonstrated in the sheep epidermis and in human and ovine placenta where chorionic plate staining was especially intense. Preabsorption of lipocortin-1 antisera on Sepharose 4B containing a limited con-. centration of recombinant lipocortin-1 produced complete ablation of lipocortin-1 immunoreactivity in the sections of placenta and lung.

The distribution and degree of immunostaining was independ. ently evaluated by three of the authors (MJ, MG, MS). Ques-. tionable areas of immunostaining were labeled as \pm , distinct but. faint immunostaining was labeled as + , and heavy staining was labeled as ++ .

\section{RESULTS}

Knowledge of the times of appearance of bronchi, defined by the presence of cartilage, and of bronchial submucosal glands, is necessary for interpreting the observations we are reporting. In the fetal lamb, cartilage can be identified in large bronchi near the hilus between 35 and $40 \mathrm{~d}$ of gestation when fetal crown-. rump length is approximately $3.6 \mathrm{~cm}(31,32)$. If subsequent development proceeds in the orderly fashion described for the human fetus (33), cartilage will form progressively in more peripheral airways as gestation proceeds. From $75 \mathrm{~d}$ of gestation onward, bronchi were located easily in fetal lambs.

Faure-Fremiet and Dragoiu (31) reported that bronchial sub-. mucosal glands first appear in the fetal lamb of about $80 \mathrm{~d}$ of 


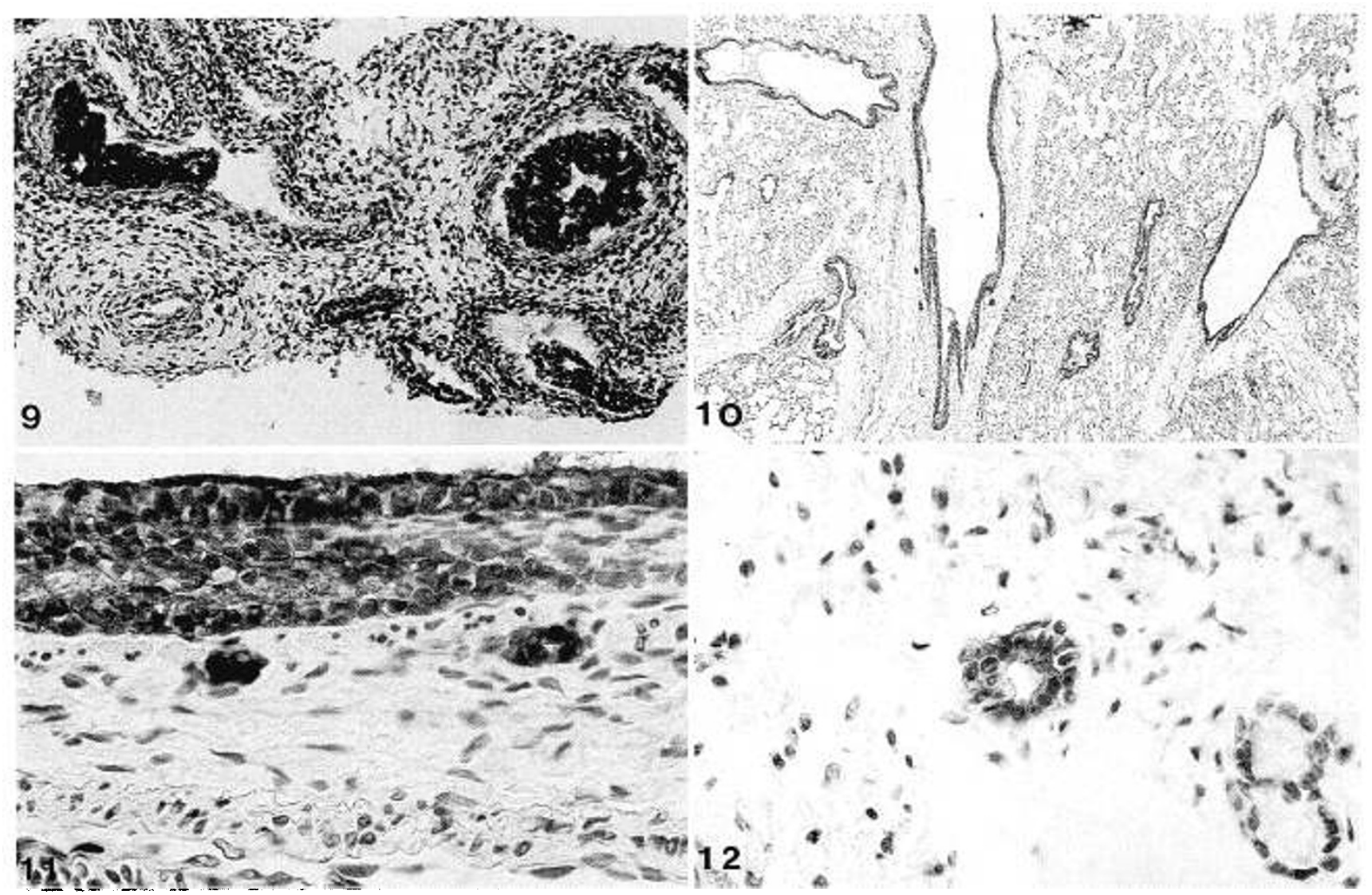

Fig. 9. Photomicrograph of the lung of a lamb of $44 \mathrm{~d}$ of gestation. Epithelial lining cells of larger conducting airways are intensely immunostained for lipocortin-1 (immunoperoxidase and hematoxylin $\times 150$ ).

Fig. 10. Photomicrograph of the lung of a lamb of $129 \mathrm{~d}$ of gestation. Bronchial epithelium and epithelium of both large and small bronchioles are intensely immunostained for lipocortin- 1 (immunoperoxidase and hematoxylin $\times 48$ ).

Fig. 11. Detail of Figure 10 showing immunostaining for lipocortin-1 of bronchial epithelium and adjacent small tubular structures which appear to be necks of glands (immunoperoxidase and hematoxylin $\times 48$ ).

Fig. 12. Photomicrograph of the lung of a lamb of $117 \mathrm{~d}$ of gestation. What appears to be a section through the neck of a submucosal gland is immunostained for lipocortin- 1 , whereas acini containing mucous cells are unstained (immunoperoxidase and hematoxylin $\times 480$ ).

gestation. At this time, solid buds from epithelial basal cells penetrate the lamina propria and form ramifying tubular structures. Acinar cells remain undifferentiated until about $130 \mathrm{~d}$ of gestation (crown-rump, $40 \mathrm{~cm}$ ) when mucous cells can be identified. Serous cells are probably differentiated slightly later.

$E G F$ receptor-IR localization (Table I). In the lungs of 44-d fetal lambs, no cartilage was identified and only questionable immunostaining of larger conducting airway epithelium was seen. However, in the lung of the 51-d lamb, where an intrapulmonary bronchus, as defined by the presence of cartilage, was identified, immunostaining for EGF receptor appeared in the lining epithelium. By $75 \mathrm{~d}$ of gestation, bronchial lining epithelium contained extensive immunoreactivity in the frozen sections (Fig. 1). Bronchial lining epithelium continued to be immunostained for EGF receptor through $129 \mathrm{~d}$ of gestation, but was absent in the near-term lambs with one exception (case 13). When bronchial submucosal glands were first identified at $90 \mathrm{~d}$ of gestation, EGF receptor immunoreactivity was present in some of the cells of the glandular epithelium (Fig. 2). Staining of cells in the bronchial submucosal glands was present from this point on in gestation with one exception (case 11) (Figs. 3, 4, 5, 6). Bronchiolar epithelial immunostaining appeared at 75 days and, with one exception, the 90-d lamb, was present throughout gestation (Fig. 7). In both bronchi and bronchioles it was the deep folds in the epithelium that contained the most intense immunoreactivity. Bronchioloalveolar portals (34), defined as points of junction between cuboidal bronchiolar and attenuated alveolar epithelia, were identified from $90 \mathrm{~d}$ onward, but first
Table 2. Appearance of lipocortin-1 immunoreactivity in the developing lamb lung*

\begin{tabular}{|c|c|c|c|c|c|}
\hline \multirow[b]{2}{*}{$\begin{array}{l}\text { Lamb } \\
\text { No. }\end{array}$} & \multirow[b]{2}{*}{$\begin{array}{l}\text { Gestational } \\
\text { age }(\mathrm{d})\end{array}$} & \multicolumn{2}{|c|}{ Bronchi } & \multirow{2}{*}{$\begin{array}{l}\text { Bronchioles } \\
\text { lining } \\
\text { epithelium }\end{array}$} & \multirow{2}{*}{$\begin{array}{c}\text { Bronchiolo- } \\
\text { alveolar } \\
\text { portals }\end{array}$} \\
\hline & & $\begin{array}{c}\text { Lining } \\
\text { epithelium }\end{array}$ & Glands & & \\
\hline 1 & 44 & 0 & 0 & $++\S$ & 0 \\
\hline 2 & 44 & 0 & 0 & $++\S$ & 0 \\
\hline 3 & 51 & 0 & 0 & $++\S$ & 0 \\
\hline 4 & 75 & ++ & + & ++ & 0 \\
\hline 5 & 75 & ++ & - & ++ & 0 \\
\hline 6 & 90 & ++ & + & ++ & ++ \\
\hline 7 & 108 & ++ & + & ++ & + \\
\hline 8 & 117 & ++ & + & ++ & ++ \\
\hline 9 & 129 & ++ & + & + & + \\
\hline 10 & 141 & ++ & + & ++ & + \\
\hline 11 & 142 & ++ & + & ++ & ++ \\
\hline 12 & 144 & ++ & + & + & + \\
\hline 13 & 145 & ++ & + & + & - \\
\hline
\end{tabular}

$*++$, heavy staining; + , faint staining; \pm , questionable staining; - , no staining identified; 0 , structure not in section; $\S$, largest conducting airways but no intrapulmonary cartilage present.

appeared immunostained for the EGF receptor in the near term lambs of 144 and $145 \mathrm{~d}$ (Fig. 8).

Lipocortin-1 localization (Table 2). In the series of lamb lung sections immunostained for lipocortin-1, no bronchi were iden- 
tified in the 44- and 51-d fetal lambs. However, two discrete size levels of conducting airway were apparent. The largest of these conducting airways were immunostained for lipocortin- 1 at both these gestational ages (Fig. 9). Because of the absence of cartilage these airways were designated as bronchioles in Table 2. Bronchi, as defined by the presence of cartilage, were first identified at 75 $\mathrm{d}$ of gestation. At this time, bronchial lining epithelium immunostained intensely for lipocortin-1 and continued to immunostain throughout the remainder of gestation (Figs. 10, 11). At 75 $\mathrm{d}$ of gestation the bronchial submucosal glands were not well differentiated, and true acini were not present. However, the epithelium lining the necks of some of the glands was immunostained (Figs. 11, 12). From $75 \mathrm{~d}$ onward, necks of the bronchial submucosal glands and some of the nonmucous acinar cells immunostained throughout the remainder of gestation (Fig. 13). Smaller, more peripheral conducting airways were not immunostained for lipocortin-1 in early gestation, but larger bronchioles were stained throughout this series of lambs (Figs. 10, 14, $15,16)$. Bronchioloalveolar portals, first identified at $90 \mathrm{~d}$, were immunostained for lipocortin-1 throughout the remainder of gestation with one exception (case 13).

\section{DISCUSSION}

Recent findings suggest that EGF and TGF- $\alpha$, another ligand for the EGF receptor, appear during the development of fetal tissues including lung (35-37), thus raising the possibility that EGF or EGF-like TGFs may influence development of the fetal lung. Fundamental to this hypothesis is the demonstration of the EGF receptor in developing lung tissue in vivo. Data presented here shows that EGF receptor immunoreactivity is present in the developing ovine lung from $51 \mathrm{~d}$ gestation onward. A similar ontogeny of EGF-binding sites has been demonstrated in ovine and mouse liver which exhibit EGF-binding sites by midgestation and an increase in EGF receptor before birth $(36,38)$. In the human fetus, bronchial epithelia initially exhibit EGF receptor immunoreactivity near the end of the first trimester; immunoreactivity in bronchial glands appears shortly thereafter (Johnson M, unpublished data). During fetal development, EGF receptor synthesis may, therefore, coincide with fetal production or transplacental passage of its ligands.

EGF receptor immunoreactivity was demonstrated only in epithelial cells lining conducting airways or peribronchial glands. In a previous study, we have shown that EGF administration stimulated proliferation of tracheal and bronchial epithelium in the ovine fetus (4). The apparent diminution or loss of EGFreceptor immunoreactivity in conducting airway epithelium in late gestation, despite continued EGF receptor immunoreactivity presence in the epithelium of peribronchial glands, may merely reflect reductions in EGF receptor concentrations during differentiation below the detection limits of our immunohistochemistry. Alternatively, it is conceivable that EGF receptor synthesis wanes as differentiation of respiratory epithelium proceeds.

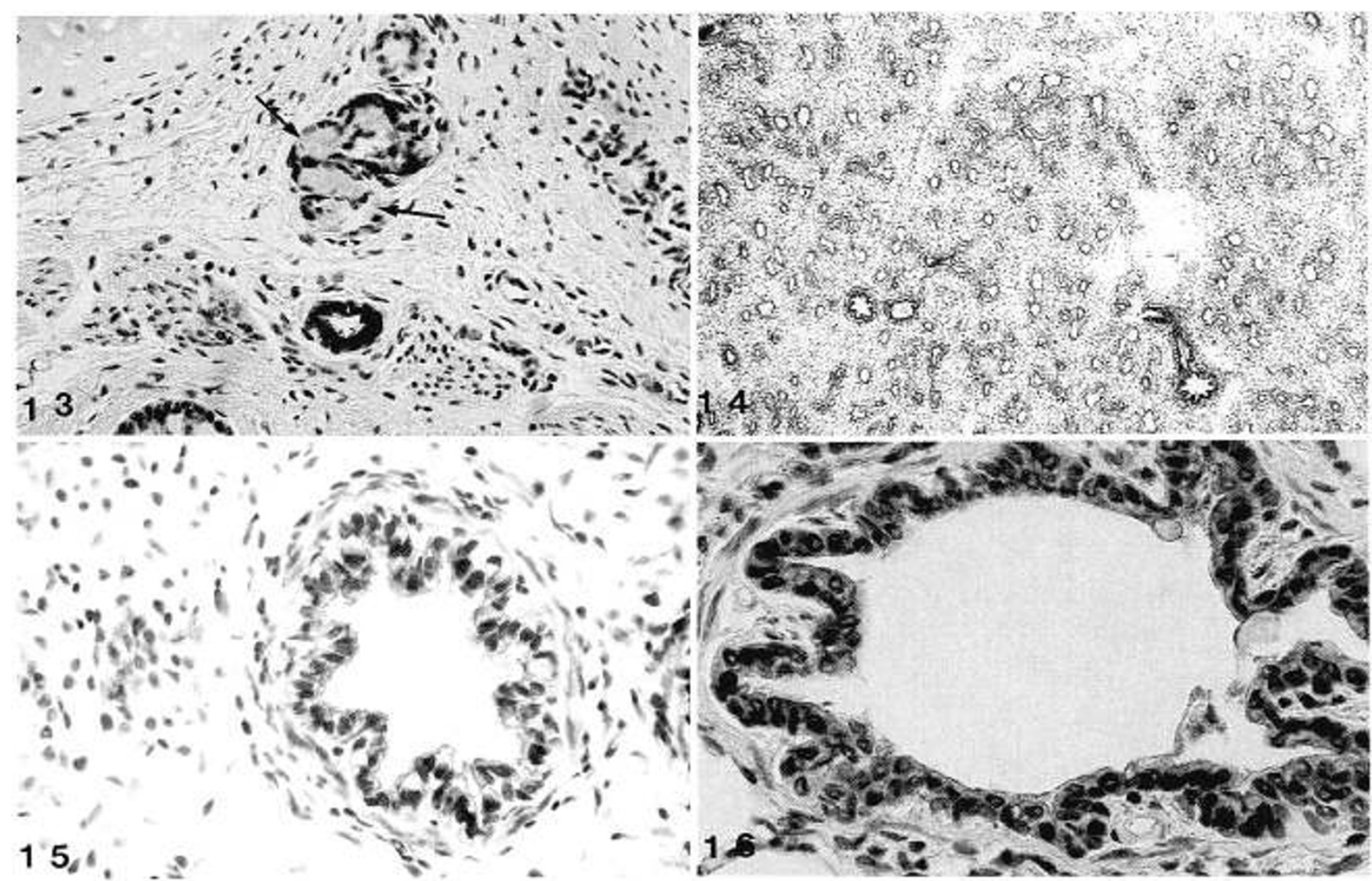

Fig. 13. Photomicrograph of the lung of a lamb of $144 \mathrm{~d}$ of gestation. Serous demilunes of submucosal glands show immunostaining for lipocortin-1. Acini primarily made up of mucous cells (arrows) are unstained. Cross-section of gland duct is intensely immunostained (immunoperoxidase and hematoxylin $\times 480$ ).

Fig. 14. Photomicrograph of the lung of a lamb of $108 \mathrm{~d}$ of gestation. Epithelial lining cells of large bronchioles are intensely immunostained for lipocortin-1 (immunoperoxidase and hematoxylin $\times 48$ ).

Fig. 15. Photomicrograph of the lung of a lamb of $117 \mathrm{~d}$ of gestation. Epithelial lining of bronchiole is immunostained for lipocortin-1 (immunoperoxidase and hematoxylin $\times 480$ ).

Fig. 16. Photomicrograph of the lung of a lamb of $144 \mathrm{~d}$ of gestation. Bronchiolar epithelium is immunostained for lipocortin-1 (immunoperoxidase and hematoxylin $\times 480$ ). 
The immunostaining of cells at bronchioloalveolar portals suggests that these cells may remain as progenitor cells for more distal airways during late gestation and possibly in the fully developed lung. Alveolar type II cells, smooth muscle cells, and fibroblasts also possess EGF receptors in vitro (11). The absence of distinct immunoreactivity in these cell types in vivo may reflect differences in EGF-receptor-gene expression in vitro and in vivo. However, the absence of EGF-receptor immunostaining in fibrocytes in vivo also suggests that the lower concentrations of EGF receptor present on nonepithelial cells might also lie below the threshold of immunodetection for our antibodies.

The significance of immunostaining of bronchial fluid is not clear. It is conceivable that some of the immunostaining reflects the presence of antibody binding fragments of epithelium carried into the lumen during the frozen sectioning process. However, it is also possible that staining was produced by unquenchable endogenous peroxidase.

The physiologic effects initiated by EGF-receptor activation late in gestation are not known. Our previous work indicated that EGF stimulated epithelial proliferation in the fetal trachea and bronchi. Nonproliferative roles for EGF have also been reported including suppression of fetal lung fluid secretion (39), stimulation of surfactant-associated protein synthesis in the lung (7) and suppression of chloride secretion in the stomach (40). Current evidence suggests that stimulation of EGF receptor/ kinase may result in phosphorylation and subsequent changes in activity in cytoplasmic or membrane bound regulatory proteins such as lipocortin-1 (13-17)

Previous studies have reported isolation of lipocortin-1 (35 $\mathrm{kD})$ from rat, porcine and bovine lung $(17,19,24)$. Immunoreactive $35 \mathrm{kD}$ protein has also been identified in the columnar epithelia of the respiratory systems of the adult mouse and rat (41). However, the ontogeny and distribution of lipocortin-1 in the developing ovine lung have not been reported. Findings reported here suggest the lipocortin-1 immunoreactivity is distributed in epithelial cells lining conducting airways and in peribronchial glands, once they appear, throughout development. Preliminary studies suggest that lipocortin-1 has a similar distribution in a series of near-normal fetal and neonatal human lungs (Johnson M, unpublished data).

The distribution of lipocortin-1 immunoreactivity is of particular interest due to its potential role as a modulator of EGF effects. Several reports suggest that lipocortin-1 is an important regulatory peptide phosphorylated by the EGF receptor/kinase (13-17). Localization of lipocortin-1 immunoreactivity at sites bearing EGF receptor immunoreactivity raises the possibility that EGF may influence cellular proliferation and differentiation by altering the activity of intracellular regulatory proteins such as lipocortin-1. The lack of complete similarity of the timing of appearance and distribution of EGF receptor immunoreactivity and lipocortin-1 immunoreactivity in this study may represent real differences in ontogeny and location, or simply concentrations of EGF receptor below the level of immunodetection with our antibodies.

Lipocortin-1, initially isolated as a substrate for the tyrosine kinase of the EGF receptor, is a calcium and phospholipiddependent membrane-binding protein that in in vitro assays inhibits phospholipase $A_{2}$ activity, binds actin, and causes lipid vesicles to aggregate $(16-18,42)$. Phosphorylation of lipocortin1 appears to alter its activity $(43,44)$; however, the physiologic effects of lipocortin-1 and thus consequences of phosphorylation are not established. The inhibitory effects of lipocortin-1 on phsopholipase $A_{2}$ have been proposed as a mechanism through which prostaglandin synthesis by inflammatory cells is inhibited $(16,17)$. Inhibitory effects on pulmonary prostaglandin synthesis have also been described by Cirino et al. (45) who found that lipocortin-1 inhibits thromboxane release in perfused guinea pig lung. Recently, Glenney et al. (18) have also demonstrated a submembrane distribution for lipocortin-1 (which they refer to as Calpactin II) and suggest that this protein acts as a membrane to a cytoskeletal linkage molecule.
In summary, the pattern of appearance of the EGF receptor/ kinase and its substrate, lipocortin-1, in ovine lung begins with immunostaining of conducting airway lining epithelium near the end of the first trimester of pregnancy before bronchial glands could be identified. The larger the airway, the earlier was the appearance of immunostaining. This was followed by staining of bronchial glands and of large bronchioles adjacent to stained bronchi at $2 / 3$ of gestation. By $7 / 8$ of gestation, conducting airway epithelium was no longer stained consistently for the EGF receptor except for the most distal cells lining bronchioloalveolar portals, but lipocortin-1 was still identified until near term in all levels of airways, including those of bronchioloalveolar portals. The most striking immunostaining for lipocortin-1 late in gestation was that in bronchial submucosal glands and the cells lining the necks of glands.

This pattern of development of the EGF receptor expression suggests early influence of EGF or EGF-like ligands on developing airway epithelium during a rapid proliferative stage. As intrapulmonary bronchial glands were identified at about $2 / 3$ of gestation and stained heavily for EGF receptor and for lipocortin1, we postulate that the EGF receptor might promote EGF action in an autocrine or paracrine fashion, as these glands also are sites of human EGF immunostaining from midgestation onward (46).

Acknowledgments. The authors wish to thank Dr. J. KamsoPratt, Mrs. Sandy Olson, Ms. Tracie Reynolds, Mr. Rao Gaddipati, Mr. Stanley Poole and Mrs. Patricia Minton for excellent technical assistance and Ms. Diana Nelson for manuscript preparation. We are also indebted to Dr. Roy Fava for helpful discussions.

\section{REFERENCES}

1. Carpenter G, Cohen S 1979 Epidermal growth factor. Ann Rev Biochem 48:193-216

2. Carpenter G 1978 The regulation of cell proliferation: advances in the biology and mechanism of action of epidermal growth factor. J Invest Dermatol $71: 283-287$

3. Kasselberg AG, Orth DN, Gray ME, Stahlman MT 1985 Immunocytochemical localization of human epidermal growth factor/urogastrone in several human tissues. J Histochem Cytochem 33:315-322

4. Sundell HW, Gray ME, Serenius FS, Escobedo MD, Stahlman MT 1980 Effects of epidermal growth factor on lung maturation in fetal lambs. Am J Pathol 100:707-726

5. Catterton WZ, Escobedo MB, Sexton WR, Gray ME, Sundell HW, Stahlman MT 1979 Effect of epidermal growth factor on lung maturation in fetal rabbits. Pediatr Res 13:104-108

6. Messmer TO, Armour R, Holley RW 1982 Factors influencing the growth of alveolar Type II epithelial cells isolated from rat lungs. Exp Cell Res 142:417426

7. Whitsett JA, Weaver TE, Lieberman MA, Clark JC, Daugherty C 1987 Differential effects of epidermal growth factor and transforming growth factor- $\beta$ on synthesis of $M_{r}=35,000$ surfactant-associated protein in fetal lung. J Biol Chem 262:7908-7913

8. Gross I, Dynia DW, Rooney SA, Smart DA, Warshaw JB, Sissom JF, Hoath SB 1986 Influence of epidermal growth factor on fetal rat lung development in vitro. Pediatr Res 20:473-477

9. Devaskar UP 1982 Epidermal growth factor receptors in fetal and maternal rabbit lung. Biochem Biophysics Res Comm 107:714-720

10. Carpenter $\mathrm{G} 1987$ Receptors for epidermal growth factor and other polypeptide mitogens. Annu Rev Biochem 56:881-914

11. Stoscheck CM, King LE, Jr 1986 Functional and structural characteristics of $\mathrm{EGF}$ and its receptor and their relationship to transforming proteins. J Cell Biochem 31:135-152

12. Ullrich A, Coussens L, Hayflick JS, Dull TJ Gray A, Tam AW, Lee J, Yardew Y, Libermann TA, Schlessinger J, Downward J, Mayes ELV, Whittle N, Waterfield MD, Seeburg PH 1984 Human epidermal growth factor receptor cDNA sequence and aberrant expression of the amplified gene in A431 epidermoid carcinoma cells. Nature 309:418-425

13. Fava RA, Cohen S 1984 Isolation of a calcium-dependent 35-kilodalton substrate for the epidermal growth factor receptor/kinase from A-431 cells. J Biol Chem 259:2636-2645

14. Sawyer ST, Cohen S 1985 Epidermal growth factor stimulates the phosphorylation of the calcium-dependent 35,000 -dalton substrate in intact A-431 cells. J Biol Chem 260:8233-8236

15. Pepinsky RB, Sinclair LK 1986 Epidermal growth factor-dependent phosphorylation of lipocortin. Nature 321:81-84

16. Brugge JS 1986 The $\mathrm{p} 35 / \mathrm{p} 36$ substrates of protein-tyrosine kinases as inhibitors of phospholipase $\mathrm{A}_{2}$. Cell 46:149-150

17. Flower RJ 1987 Lipocortins. In: Samuelsson B, Paoletti R, Ramwell PW (eds) Advances in Prostaglandin, Thromboxane, and Leukotriene Research, vol 
17. Raven Press, New York, pp 577-580

18. Glenney JR, Tack B, Powell MA 1987 Calpactins: Two distinct $\mathrm{Ca}^{++}$regulated phospholipid- and actin-binding proteins isolated from lung and placenta. $\mathrm{J}$ Cell Biol 104:503-51

19. Khanna NC, Tokuda M, Warsman DM 1987 Purification of three forms of lipocortin from bovine lung. Cell Calcium 8:217-228

20. Strott CA, Sundell HW, Stahlman MT 1974 Maternal and fetal progesterone, cortisol, testosterone and $17 \beta$-estradiol in preparturient sheep: Response to fetal ACTH infusion. Endocrinology 95:1327-1339

21. Rentrop M, Knapp B, Winter H, Schweizer J 1986 Aminoalkysilane-treated glass slides as support for in situ hybridization of keratin cDNAs to frozen tissue sections under varying fixation and pretreatment conditions. Histochem J 18:271-276

22. Stoscheck CM, Carpenter G 1983 Biology of the A-431 cell: A useful organism for hormone research. J Cell Biochem 23:191-202

23. Rygaard J 1978 The nude mouse-background, some achievements and implications. In: Jorgen F, Giovanella BC (eds) The Nude Mouse in Experimental and Clinical Research. Academic Press Inc, New York, pp 95-108

24. De BK, Misono KS, Lukas TJ, Mroczkowski B, Cohen S 1986 A calciumdependent 35-kilodalton substrate for epidermal growth factor receptor/ kinase isolated from normal tissue. J Biol Chem 261:13784-13792

25. Stoscheck CM, Carpenter G 1983 Characteristics of antibodies to the epidermal growth factor receptor-kinase. Arch Biochem Biophys 227:457-468

26. Stoscheck CM, Carpenter G 1984 Down regulation of epidermal growth factor receptors: direct demonstration of receptor degradation in human fibroblasts. J Cell Biol 98:1048-1053

27. Sternberger LA, Hardy PH Jr, Cuculis JJ, Meyer HG 1970 The unlabeled antibody enzyme method of immunohistochemistry. Preparation and properties of soluble antigen-antibody complex (horseradish peroxidase,-antihorseradish peroxidase) and its use in identification of spirochetes. J Histochem Cytochem 18:315-333

28. Werner MH, Nanney LB, Stoscheck CM, King LE 1988 Localization of immunoreactive epidermal growth factor receptors in human nervous system. J Histochem Cytochem 36:81-86

29. Capel PJA 1974 A quantitative immunofluorescence method based on the covalent coupling of protein to Sepharose beads. J Immunol Methods 5:165178

30. Huang K-S, Wallner BP, Mattaliano RJ, Tizard R, Burne C, Frey A, Hession C McGray P, Sinclair LK, Chow EP, Browning JL, Ramachandran KL, Tang J Smart JE, Pepinsky RB 1986 Two human 35Kd inhibitors of phospholipase $\mathrm{A}_{2}$ are related to substrates of $\mathrm{pp} 60^{\mathrm{v}-\mathrm{src}}$ and of the epidermal phospholipase $A_{2}$ are related to substrates of pp
growth factor receptor/kinase. Cell 46:191-199

31. Faure-Fremiet E, Dragoiu J 1923 Le developpment du poumon foetal chez le mouton. Arch d'Anat Micr 29:411-474

32. Barcroft J 1946 In: Researches on Pre-Natal Life, vol 1. The growth of the body and its constituent parts. Blackwell Scientific Publications, Ltd, Oxford, pp 29-41

33. de Haller R 1969 Development of mucus-secreting elements. In: J Emery (ed) The Anatomy of the Developing Lung. Spastics International Medical Publications. Lavenham, Suffolk, pp 94-115

34. Hoyte RF Jr, Sorokin SP, Feldman H 1982 Small-granule (neuro)endocrine cells in the infracardiac lobe of a hamster lung: number, subtypes and distribution. Exp Lung Res 3:273-298

35. Rall BL, Scott J, Graeme IB, Crawford RJ, Penschow JD, Niall HD, Coghlan FP 1985 Mouse prepro-epidermal growth factor synthesis by the kidney and other tissues. Nature 313:228-231

36. Freemark M, Comer M 1987 Epidermal growth factor (EGF)-like transforming growth factor (TGF) activity and EGF receptors in ovine fetal tissues: Possible role for TGF in ovine fetal development. Pediatr Res 22:609-615

37. Twardzik DR 1985 Differential expression of transforming growth factor- $\alpha$ during prenatal development of the mouse. Cancer Res 45:5413-5416

38. Adamson ED, Meek J 1984 The ontogeny of epidermal growth factor receptors during mouse development. Dev Biol 103:62-70

39. Kennedy KA, Wilton P, Mellander M, Rojas J, Sundell H 1986 Effect of epidermal growth factor on lung liquid secretion in fetal sheep. J Dev Physiol 8:421-433

40. Gregory H 1975 Isolation and structure of urogastrone and its relationship to epidermal growth factor. Nature 257:325-327

41. McKanna JA, Cohen S 1985 Morphological analysis of a phosphorylation substrate of the EGF receptor/kinase. J Cell Biol 101:300a

42. Creutz CE, Zaks WJ, Hamman HC, Crane S, Martin WH, Gould KL, Oddie KM, Parsons SJ 1987 Identification of chromaffin granule-binding proteins: relationship of the chromobindins to calelectrin, synhibin and tyrosine kinase substrates p35 and p36. J Biol Chem 262:1860-1868

43. Powell MA, Glenney JR 1987 Regulation of calpactin I phospholipid binding by calpactin I light-chain binding and phosphorylation by $060^{\text {v-src }}$. Biochem J 247:321-328

44. Schlaepfer DD, Haigler HT 1987 Characterization of $\mathrm{Ca}^{2+}$-dependent phospholipid binding and phosphorylation of lipocortin-1. J Biol Chem 262:6931-6937

45. Cirino G, Flower RJ, Browning JL, Sinclair LK, Pepinsky RB 1987 Recombinant human lipocortin-1 inhibits thromboxane release from guinea-pig isolated perfused lung. Nature 328:270-272

46. Stahlman MT Orth DN Gray ME 1989 Immunocytochemical localization of epidermal growth factor in the developing human respiratory system and in acute and chronic lung disease in the neonate. Lab Invest, in press 